\title{
Pola Pertumbuhan Ayam Broiler Strain Lohmann Berdasarkan Osteometri Tulang Sayap
}

\author{
The Growth Patterns of Broiler Lohmann Strains Based on Forelimb Bone Osteometry
}

\author{
Neneng Ismi Megawati ${ }^{1 *}$, Yeni Dhamayanti², Muhammad Thohawi Elziyad Purnama², \\ Soeharsono $^{2}$, Aditya Yudhana ${ }^{3}$, Maya Nurwartanti Yunita ${ }^{4}$ \\ ${ }^{1}$ Mahasiswa, ${ }^{2}$ Departemen Anatomi Veteriner, ${ }^{3}$ Departemen Parasitologi Veteriner, ${ }^{4}$ Departemen Patologi \\ Veteriner, Fakultas Kedokteran Hewan, Universitas Airlangga \\ Kampus C Mulyorejo, Surabaya, Jawa Timur, Indonesia 60115 \\ *Corresponding author: nenengismimega@gmail.com
}

\begin{abstract}
Abstrak
Tujuan dari penelitian ini adalah untuk mengetahui pola pertumbuhan dan osteometri serta untuk mengetahui titik osteometri tulang sayap ayam broiler strain Lohmann. Pengukuran tulang sayap dilakukan dengan mengukur panjang, lebar, keliling dan barat tulang dengan menggunakan jangka sorong dengan ketelitian 0,05 mm. Hasil penelitian pola pertumbuhan ayam broiler strain Lohmann tulang sayap pada umur 7 , 21 dan 35 hari, diperoleh hasil yang signifikan $(\mathrm{p}<0.05)$ terhadap nilai rata-rata panjang, lebar (proximal, corpus dan distal), keliling (proximal, corpus dan distal) dan berat pada os scapula, os coracoid dan os clavicula dan tulang-tulang alat penyusun gerak bebas yang terdiri dari os humerus, os radius, os ulna, os metacarpal I, os metacarpal II, os metacarpal III, ossa digiti I, ossa digiti II dexter phalang I dan Phalang II, ossa digiti II sinister Phalang I dan Phalang II serta os digiti III. Data di analisis menggunakan Analysis of Variance (ANOVA) selanjutnya diuji menggunakan uji Post Hoc Duncan. Ayam broiler strain Lohmann memiliki titik pertumbuhan maksimum saat berumur 21 hari yang ditunjukkan dengan terlihat ada titik optimal dan di lanjutkan dengan pertumbuhan yang melambat. Pada titik ini memicu pembentukan daging pada ayam broiler strain Lohmann sebelum ayam mencapai batas pertumbuhan.
\end{abstract}

Kata kunci: ayam broiler, osteometri, tulang sayap

\section{Abstract}

The aim of this study was to determine the growth pattern and osteometry of the the Lohmann strain broiler chicken, and the osteometry points, of forelimb bone. The measurement of the wing bone was done in the lenght, width, circumference and weight of the bone using a calipers with an accuracy of $0.05 \mathrm{~mm}$. The result showed that the Lohmann strain broiler chicken growth patterns based on forelimb bone osteometry at 7, 21 and 35 days, concluced that there were significant result $(p<0.05)$ to the average length, width (proximal, corpus and distal), circumference (proximal, corpus and distal) and weight on the os scapula, os coracoid and os clavicula and the bone of the free motion constituents consisting of the os humerus, os radius, os ulna, os metacarpal I, os metacarpal II, os metacarpal III, ossa digiti I, ossa digiti II dexter phalang I dan Phalang II, ossa digiti II sinister Phalang I dan PhalangI I serta os digiti III. Data was analyzed using Analysis of Variance (ANOVA) then continued with Post Hoc Duncan test. The growth point reached its maximum when the 21 day old chicken was indicated by an optimal point and followed by slowing growth. At this point triggers the formation of meat in the Lohmann strain broiler chicken before the chicken reach the growth limit.

Keywords: broiler chicken, osteometry, forelimb bone

Received: 8 Januari 2020

Revised: 12 Februari 2020

Accepted: 13 Maret 2020

\section{PENDAHULUAN}

Ayam broiler merupakan ayam unggul yang berasal dari persilangan antar bangsa ayam sehingga mempunyai produktivitas tinggi. Ayam broiler diseleksi sistematis sehingga tumbuh dan mencapai bobot badan tertentu dalam kurun waktu yang cepat (Murwani, 2010). Yuwanta (2004) menyatakan bahwa ayam broiler memiliki karakteristik khusus dengan pertumbuhan yang cepat, sehingga masa panen ayam broiler relatif singkat. Penambahan bobot 
badan pada minggu pertama mencapai empat kali bobot pada saat Day Old Chick (DOC) bila ditunjang dengan nutrisi yang optimal. Masyarakat Indonesia memelihara ayam broiler untuk diambil dagingnya sebagai sumber protein hewani (Murwani, 2010).

Ayam broiler dipelihara secara intensif yaitu sistem pemeliharaan dikandangkan. Kandang yang biasa digunakan untuk memeliharaan ayam broiler adalah kandang dengan sistem litter (Muharlien dkk., 2011). Pemeliharaan sistem intensif, pakan diberikan secara rutin yang disediakan oleh peternak dengan jumlah dan kandungan kebutuhan sesuai dengan yang dibutuhkan oleh ayam tersebut (Pramudyati, 2009; Kartikasari et al., 2019).

Wilson et al. (1983) menyampaikan bahwa beberapa faktor seperti genetik, pakan dan fungsi hormonal dapat mempengaruhi pertumbuhan dan perkembangan jaringan tulang sehingga mempengaruhi laju pertumbuhan bentuk tulang serta ukuran tulang (Rahmaningtyas et al., 2017). Pakan dibutuhkan untuk pembentukan tulang. Pakan yang mengandung protein salah satunya lisin yang digunakan untuk dasar pertumbuhan pada sel tulang (Rizkuna, 2014).

Lisin dibutuhkan oleh ternak karena asam amino lisin berfungsi dalam pertumbuhan ayam untuk menunjang proses penyerapan kalsium dalam pembentukan tulang (Harland dan Oberleas, 2001). Corzo et al. (2002) menyatakan bahwa pertumbuhan ayam tergantung dari kandungan protein dan asam amino pada ransum yang dikonsumsi oleh ayam tersebut.

Bangun dkk. (2013) menyebutkan bahwa proses pertumbuhan tulang berjalan beriringan dengan pertambahan berat, panjang dan lebar tulang. Pembentukan tulang merupakan mekanisme awal kemudian dilanjutkan dengan pertambahan ukuran tulang yang melalui proses kalsifikasi tulang, demikian juga dalam penelitian Djagra (2002) yang menjelaskan bahwa pertumbuhan tulang dapat memberi pengaruh terhadap panjang badan dan bobot badan, sedangkan pertumbuhan daging dapat mempengaruhi lebar dada, lingkar dada, lingkar perut dan bobot badan.
Sifat kualitatif merupakan sifat yang tampak akan tetapi tidak dapat diukur dengan satuan ukuran tertentu. Sifat kualitatif meliputi sifat fisik yang termasuk dalam bagian-bagian tubuh seperti jaringan atau organ tubuh dan perilaku secara fisiologis yang dikendalikan oleh gen-gen yang terdapat didalam kromosom. Sifat kuantitatif merupakan sifat yang dapat diukur dengan satuan ukuran tertentu. Berdasarkan sifat kuantitatif, sifat fenotip pada ternak dapat teramati (Warwick dkk., 1990).

Sifat kuantitatif yang menentukan morfologi pada ayam salah satu adalah sayap. Tulang sayap merupakan salah satu tulang yang sering digunakan untuk beraktivitas sehingga pertumbuhannya terus meningkat secara optimal (Rahayu dkk., 2019). Uraian-uraian di atas menjadi dasar pemikiran terhadap pola pertumbuhan dan osteometri tulang, khususnya tulang-tulang penyusun sayap. Penelitian pertumbuhan tulang yang mengkaji osteometri tulang-tulang pada sayap ayam broiler khususnya pada strain Lohmann masih belum ada.

\section{METODE PENELITIAN}

Ethical clearance dilakukan sebelum penelitian dimulai dan dibuktikan dengan sertifikat No.768/HRECC.FODM/XII/2019.

Penelitian observasional dilakukan dengan pengambilan data dari pengukuran osteometri tulang sayap ayam broiler strain Lohmann. Hewan coba yang dipakai dalam penelitian ini adalah ayam broiler strain Lohmann dengan umur 7, 21 dan 35 hari. Hewan coba yang digunakan berjenis kelamin betina dengan jumlah 10 ekor.

Sampel pada penelitian ini adalah tulang sayap bagian dexter dan sinister. Tulang sayap terbagi atas tulang bahu dan tulang-tulang penyusun alat gerak bebas. Bagian tulang bahu terdiri dari tiga buah tulang, yaitu os scapula, os coracoid dan os clavicula sedangkan tulangtulang penyusun alat gerak bebas terdiri dari os humerus, os radius, os ulna, os metacarpal I, os metacarpal II, os metacarpal III, ossa digiti I, ossa digiti II dexter phalang I dan Phalang II, 
ossa digiti II sinister Phalang I dan Phalang II dan ossa digiti III.

Bahan yang digunakan dalam penelitian ini adalah $\mathrm{NaOH} 3 \%$ dan sayap ayam broiler strain Lohmann (Singh et al., 2015). Alat yang digunakan dalam penelitian adalah pisau, alat bedah (scalpel, gunting, pinset), caliper, penggaris, benang, oven, alumunium foil, kertas label, panci, timbangan Porteble $\left(\right.$ Scout $^{\circledR}$ Pro AP) dengan ketelitian 1 gram, Timbangan gantung, kompor, masker dan sarung tangan.

Ayam broiler strain Lohmann diambil dari peternakan di Kedayunan Kabupaten Banyuwangi. Sampel yang diambil adalah ayam umur 7, 21 dan 35 hari. Masing-masing berjumlah 10 ekor. Setelah itu, sampel tersebut dibawa ke laboratorium Anatomi Prodi Kedokteran Hewan Program Studi diluar Kampus Utama (PSDKU) Universitas Airlangga di Banyuwangi.

Ayam sebelum dieutanasi ditimbang terlebih dahulu untuk mendapatkan data bobot hidup (Kurniawan dkk., 2012). Ayam yang telah di eutanasi, dibersihkan bulu-bulunya dan dilanjutkan dengan pengeluaran organ. Sayap kanan dan kiri dibedah dengan menggunakan pisau. Otot, tendon, ligamen dan jaringan lunak lainnya dipisahkan dengan kerangka menggunakan pisau bedah (Vistro, 2015). Tulang sayap di masukkan dalam larutan $\mathrm{NaOH}$ $3 \%$. Otot yang masih menempel pada tulang dibersihkan dengan menggunakan alat bedah seperti pinset dan scalpel (Singh et al., 2015).

Tulang yang telah bersih di bungkus menggunakan alumunium foil dan di beri label sesuai dengan nama tulang. Oven tulang selama 2-6 jam (sesuai dengan usia ayam broiler) dengan suhu $100^{\circ} \mathrm{C}$. Total 25 sampel tulang untuk satu ekor ayam. Pengukuran dilakukan dengan menghitung panjang, lebar dan keliling pada setiap tulang menggunakan jangka sorong (vernier caliper) dengan ketelitian 0,05 mm.

Lebar diukur pada bagian terlebar di bagian anterior dan posterios tulang. Keliling atau lingkar tulang di ukur menggunakan benang yang dilingkarkan ke tulang lalu diukur panjang benang tersebut menggunakan jangka sorong (Hartadi et al., 2018).
Data yang diperoleh disajikan secara kuantitatif. Perbedaan morfometri tulangtulang pada sayap untuk spesies yang berbeda di uji menggunakan Analysis of Variance (ANOVA). Data yang tampak signifikan $(\mathrm{p}<0.05)$ selanjutnya diuji menggunakan uji Post Hoc Duncan. Data-data yang diperoleh dianalisis dengan menggunakan perangkat lunak IBM SPSS statistics 20 (Vistro, 2015).

\section{HASIL DAN PEMBAHASAN}

Hasil data yang diperoleh dalam penelitian ini yaitu Bobot badan ayam broiler strain Lohmann yang di timbang setiap umur 7, 21 dan 35 hari serta pengukuran osteometri tulang sayap pada ayam broiler strain lohmann. Hewan coba di timbang untuk mengetahui bobot badan di setiap periodenya (Tabel 1).

Berdasarkan hasil yang diperoleh dari perhitungan bobot badan ayam broiler strain Lohmann (Tabel 1) yang menunjukkan hasil yang signifikan $(p<0.05)$ di setiap periode pengambilan, dengan rata-rata hasil perhitungan bobot badan pada umur 7 hari sebesar 153,45, pada umur 21 hari sebesar 941,80 dan 35 hari sebesar 1573,60 gram. Rata-rata bobot badan ayam semakin meningkat seiring bertambahnya umur ayam. Pertambahan bobot badan ayam merupakan salah satu cara untuk mengukur pertumbuhan ayam broiler dan dijadikan sebagai tolok ukur dalam menentukan bobot badan akhir pada ayam broiler (Triawan dkk., 2013).

Hasil penelitian didapatkan dari pengukuran tulang sayap ayam broiler bagian tulang bahu dan tulang-tulang penyusun alat gerak bebas dengan menggunakan jangka sorong dengan ketelitian $0,05 \mathrm{~mm}$. Bagian tulang bahu terdiri dari tiga buah tulang, yaitu os scapula, os coracoid dan os clavicula sedangkan tulangtulang alat penyusun gerak bebas terdiri dari os humerus, os radius, os ulna, os metacarpal I, os metacarpal II, os metacarpal III, ossa digiti I, ossa digiti II phalang I ossa digiti II Phalang I dan ossa digiti II Phalang II serta ossa digiti III (Tabel 2).

Berdasarkan hasil yang diperoleh dari pengukuran tulang sayap ayam broiler (Tabel 2) 
Tabel 1. Rata-rata dan standart deviasi hasil perhitungan bobot badan ayam broiler strain Lohmann

\begin{tabular}{|c|c|c|c|}
\hline \multirow{2}{*}{ Variabel } & \multicolumn{3}{|c|}{ Hari (Mean \pm SD) } \\
\hline & 7 & 21 & 35 \\
\hline Bobot badan (gram) & $153,45^{\mathrm{a}} \pm 18,97$ & $941,80^{\mathrm{b}} \pm 94,42$ & $1573,60^{c} \pm 221,67$ \\
\hline
\end{tabular}

Tabel 2. Rata-rata dan standart deviasi osteometri ayam broiler strain Lohmann

\begin{tabular}{|c|c|c|c|}
\hline \multirow{2}{*}{ Variabel } & \multicolumn{3}{|c|}{ Hari (Mean \pm SD) } \\
\hline & 7 & 21 & 35 \\
\hline Length Scap. Dex & $2,44^{\mathrm{a}} \pm 0,13$ & $4,59^{\mathrm{b}} \pm 0,14$ & $5,67^{c} \pm 0,16$ \\
\hline Length Scap. Sin & $2,42^{\mathrm{a}} \pm 0,12$ & $4,59^{b} \pm 0,13$ & $5,67^{c} \pm 0,17$ \\
\hline Length Corac. Dex & $1,82^{\mathrm{a}} \pm 0,99$ & $3,44^{\mathrm{b}} \pm 0,13$ & $4,30^{c} \pm 0,14$ \\
\hline Length Corac. Sin & $1,80^{\mathrm{a}} \pm 0,09$ & $3,45^{\mathrm{b}} \pm 0,13$ & $4,31^{\mathrm{c}} \pm 0,14$ \\
\hline Length clavic & $1,79^{\mathrm{a}} \pm 0,11$ & $3,48^{b} \pm 0,06$ & $4,62^{\mathrm{c}} \pm 0,21$ \\
\hline Width Scap. Dex. Prox & $0,52^{\mathrm{a}} \pm 0,09$ & $1,05^{\mathrm{b}} \pm 0,09$ & $1,29^{c} \pm 0,03$ \\
\hline Width Scap. Dex. Cor & $0,25^{\mathrm{a}} \pm 0,04$ & $0,57^{\mathrm{b}} \pm 0,04$ & $0,64^{\mathrm{c}} \pm 0,04$ \\
\hline Width Scap. Dex. Dis & $0,28^{\mathrm{a}} \pm 0,06$ & $0,52^{b} \pm 0,03$ & $0,58^{\mathrm{c}} \pm 0,02$ \\
\hline Width Scap. Sin. Prox & $0,52^{\mathrm{a}} \pm 0,09$ & $1,05^{\mathrm{b}} \pm 0,09$ & $1,28^{\mathrm{c}} \pm 0,04$ \\
\hline Width Scap. Sin. Cor & $0,25^{\mathrm{a}} \pm 0,05$ & $0,58^{\mathrm{b}} \pm 0,05$ & $0,65^{\mathrm{c}} \pm 0,04$ \\
\hline Width Scap. Sin. Dis & $0,28^{\mathrm{a}} \pm 0,05$ & $0,51^{\mathrm{b}} \pm 0,03$ & $0,59^{c} \pm 0,02$ \\
\hline Width Corac. Dex. Prox & $0,36^{\mathrm{a}} \pm 0,04$ & $0,68^{\mathrm{b}} \pm 0,04$ & $0,77^{\mathrm{c}} \pm 0,04$ \\
\hline Width Corac. Dex. Cor & $0,26^{\mathrm{a}} \pm 0,05$ & $0,50^{\mathrm{b}} \pm 0,03$ & $0,57^{\mathrm{c}} \pm 0,02$ \\
\hline Width Corac. Dex. Dis & $0,59^{a} \pm 0,07$ & $1,21^{\mathrm{b}} \pm 0,07$ & $1,50^{c} \pm 0,05$ \\
\hline Width Corac. Sin. Prox & $0,36^{\mathrm{a}} \pm 0,05$ & $0,68^{\mathrm{b}} \pm 0,04$ & $0,77^{\mathrm{c}} \pm 0,04$ \\
\hline Width Corac. Sin. Cor & $0,26^{\mathrm{a}} \pm 0,05$ & $0,50^{\mathrm{b}} \pm 0,03$ & $0,57^{\mathrm{c}} \pm 0,02$ \\
\hline Width Corac. Sin. Dis & $0,55^{\mathrm{a}} \pm 0,06$ & $1,22^{\mathrm{b}} \pm 0,06$ & $1,52^{\mathrm{c}} \pm 0,05$ \\
\hline Circul Scap. Dex. Prox & $0,72^{\mathrm{a}} \pm 0,06$ & $1,37^{\mathrm{b}} \pm 0,08$ & $1,63^{c} \pm 0,13$ \\
\hline Circul Scap. Dex. Cor & $0,63^{\mathrm{a}} \pm 0,08$ & $1,43^{\mathrm{b}} \pm 0,11$ & $1,57^{\mathrm{c}} \pm 0,07$ \\
\hline Circul Scap. Dex. Dis & $0,70^{\mathrm{a}} \pm 0,09$ & $1,44^{\mathrm{b}} \pm 0,11$ & $1,47^{b} \pm 0,08$ \\
\hline Circul Scap. Sin. Prox & $0,72^{\mathrm{a}} \pm 0,06$ & $1,37^{\mathrm{b}} \pm 0,08$ & $1,50^{c} \pm 0,06$ \\
\hline Circul Scap. Sin. Cor & $0,63^{\mathrm{a}} \pm 0,08$ & $1,42^{\mathrm{b}} \pm 0,11$ & $1,57^{\mathrm{c}} \pm 0,06$ \\
\hline Circul Scap. Sin. Dis & $0,67^{\mathrm{a}} \pm 0,06$ & $1,39^{\mathrm{b}} \pm 0,13$ & $1,50^{\mathrm{c}} \pm 0,06$ \\
\hline Circul Corac. Dex. Prox & $0,95^{\mathrm{a}} \pm 0,06$ & $1,71^{\mathrm{b}} \pm 0,08$ & $2,09^{c} \pm 0,07$ \\
\hline Circul Corac. Dex. Cor & $0,89^{\mathrm{a}} \pm 0,07$ & $1,74^{\mathrm{b}} \pm 0,09$ & $2,11^{\mathrm{c}} \pm 0,09$ \\
\hline Circul Corac. Dex. Dis & $1,24^{\mathrm{a}} \pm 0,10$ & $2,66^{\mathrm{b}} \pm 0,07$ & $3,10^{c} \pm 0,13$ \\
\hline Circul Corac. Sin. Prox & $0,98^{\mathrm{a}} \pm 0,08$ & $1,74^{\mathrm{b}} \pm 0,05$ & $2,14^{\mathrm{c}} \pm 0,07$ \\
\hline Circul Corac. Sin. Cor & $0,88^{\mathrm{a}} \pm 0,09$ & $1,76^{\mathrm{b}} \pm 0,08$ & $2,10^{c} \pm 0,09$ \\
\hline Circul Corac. Sin. Dis & $1,22^{\mathrm{a}} \pm 0,13$ & $2,66^{\mathrm{b}} \pm 0,10$ & $3,23^{c} \pm 0,28$ \\
\hline Weight Scap. Dex & $0,04^{\mathrm{a}} \pm 0,01$ & $0,35^{\mathrm{b}} \pm 0,05$ & $0,61^{\mathrm{c}} \pm 0,03$ \\
\hline Weight Scap. Sin & $0,03^{\mathrm{a}} \pm 0,01$ & $0,35^{\mathrm{b}} \pm 0,06$ & $0,61^{\mathrm{c}} \pm 0,04$ \\
\hline Weight Corac. Dex & $0,08^{\mathrm{a}} \pm 0,02$ & $0,61^{\mathrm{b}} \pm 0,07$ & $1,24^{\mathrm{c}} \pm 0,10$ \\
\hline Weight Corac. Sin & $0,07^{\mathrm{a}} \pm 0,02$ & $0,63^{\mathrm{b}} \pm 0,06$ & $1,25^{\mathrm{c}} \pm 0,11$ \\
\hline Weight Clavic & $0,02^{\mathrm{a}} \pm 0,01$ & $0,26^{\mathrm{b}} \pm 0,03$ & $0,53^{c} \pm 0,08$ \\
\hline Length Humer. Dex & $2,44^{\mathrm{a}} \pm 0,20$ & $4,55^{\mathrm{b}} \pm 0,16$ & $5,80^{c} \pm 0,14$ \\
\hline Length Humer. Sin & $2,50^{\mathrm{a}} \pm 0,11$ & $4,55^{\mathrm{b}} \pm 0,16$ & $5,82^{\mathrm{c}} \pm 0,13$ \\
\hline Length Radi. Dex & $2,18^{\mathrm{a}} \pm 0,15$ & $4,20^{\mathrm{b}} \pm 0,12$ & $5,32^{\mathrm{c}} \pm 0,12$ \\
\hline Length Radi. Sin & $2,22^{\mathrm{a}} \pm 0,14$ & $4,20^{\mathrm{b}} \pm 0,11$ & $5,32^{\mathrm{c}} \pm 0,12$ \\
\hline Length Ulna. Dex & $2,27^{\mathrm{a}} \pm 0,14$ & $4,39^{\mathrm{b}} \pm 0,14$ & $5,58^{\mathrm{c}} \pm 0,14$ \\
\hline Length Ulna. Sin & $2,30^{\mathrm{a}} \pm 0,11$ & $4,38^{\mathrm{b}} \pm 0,11$ & $5,56^{\mathrm{c}} \pm 0,12$ \\
\hline Length Meta I Dex & $0,22^{\mathrm{a}} \pm 0,04$ & $0,52^{b} \pm 0,05$ & $0,61^{\mathrm{c}} \pm 0,03$ \\
\hline Length Meta I Sin & $0,21^{\mathrm{a}} \pm 0,05$ & $0,54^{\mathrm{b}} \pm 0,05$ & $0,62^{c} \pm 0,03$ \\
\hline Length Meta II Dex & $1,48^{\mathrm{a}} \pm 0,12$ & $2,63^{\mathrm{b}} \pm 0,09$ & $3,26^{\mathrm{c}} \pm 0,07$ \\
\hline Length Meta II Sin & $1,49^{\mathrm{a}} \pm 0,11$ & $2,58^{\mathrm{b}} \pm 0,07$ & $3,26^{\mathrm{c}} \pm 0,05$ \\
\hline Length Meta III Dex & $1,33^{\mathrm{a}} \pm 0,11$ & $2,33^{\mathrm{b}} \pm 0,07$ & $2,92^{\mathrm{c}} \pm 0,07$ \\
\hline Length Meta III Sin & $1,29^{\mathrm{a}} \pm 0,10$ & $2,33^{\mathrm{b}} \pm 0,08$ & $2,90^{\mathrm{c}} \pm 0,07$ \\
\hline
\end{tabular}




\begin{tabular}{|c|c|c|c|}
\hline Length Digit I Dex & $0,52^{\mathrm{a}} \pm 0,04$ & $0,99^{\mathrm{b}} \pm 0,04$ & $1,26^{\mathrm{c}} \pm 0,06$ \\
\hline Length Digit I Sin & $0,53^{\mathrm{a}} \pm 0,05$ & $0,99^{\mathrm{b}} \pm 0,05$ & $1,23^{\mathrm{c}} \pm 0,06$ \\
\hline Length Digit II Dex. Phal. I & $0,54^{\mathrm{a}} \pm 0,04$ & $1,14^{\mathrm{b}} \pm 0,06$ & $1,38^{\mathrm{c}} \pm 0,05$ \\
\hline Length Digit II Sin. Phal. I & $0,56^{\mathrm{a}} \pm 0,05$ & $1,15^{\mathrm{b}} \pm 0,06$ & $1,39^{\mathrm{c}} \pm 0,06$ \\
\hline Length Digit II Dex. Phal. II & $0,47^{\mathrm{a}} \pm 0,05$ & $1,00^{\mathrm{b}} \pm 0,04$ & $1,20^{\mathrm{c}} \pm 0,07$ \\
\hline Length Digit II Sin. Phal. II & $0,50^{\mathrm{a}} \pm 0,07$ & $1,00^{\mathrm{b}} \pm 0,04$ & $1,20^{\mathrm{c}} \pm 0,06$ \\
\hline Length Digit III Dex & $0,30^{\mathrm{a}} \pm 0,09$ & $0,54^{\mathrm{b}} \pm 0,04$ & $0,68^{\mathrm{c}} \pm 0,06$ \\
\hline Length Digit III Sin & $0,25^{\mathrm{a}} \pm 0,03$ & $0,55^{\mathrm{b}} \pm 0,05$ & $0,66^{\mathrm{c}} \pm 0,04$ \\
\hline Width Humer. Dex. Prox & $0,71^{\mathrm{a}} \pm 0,06$ & $1,39^{b} \pm 0,05$ & $1,75^{\mathrm{c}} \pm 0,04$ \\
\hline Width Humer. Dex. Cor & $0,36^{\mathrm{a}} \pm 0,03$ & $0,55^{\mathrm{b}} \pm 0,02$ & $0,70^{\mathrm{c}} \pm 0,03$ \\
\hline Width Humer. Dex. Dis & $0,60^{\mathrm{a}} \pm 0,07$ & $1,14^{\mathrm{b}} \pm 0,06$ & $1,42^{\mathrm{c}} \pm 0,04$ \\
\hline Width Humer. Sin. Prox & $0,70^{\mathrm{a}} \pm 0,06$ & $1,35^{\mathrm{b}} \pm 0,20$ & $1,42^{\mathrm{c}} \pm 0,04$ \\
\hline Width Humer. Sin. Cor & $0,37^{\mathrm{a}} \pm 0,03$ & $0,56^{\mathrm{b}} \pm 0,02$ & $0,70^{\mathrm{c}} \pm 0,03$ \\
\hline Width Humer. Sin. Dis & $0,58^{\mathrm{a}} \pm 0,06$ & $1,16^{\mathrm{b}} \pm 0,57$ & $1,42^{\mathrm{c}} \pm 0,03$ \\
\hline Width Radi. Dex. Prox & $0,25^{\mathrm{a}} \pm 0,03$ & $0,53^{b} \pm 0,02$ & $0,64^{\mathrm{c}} \pm 0,02$ \\
\hline Width Radi. Dex. Cor & $0,13^{\mathrm{a}} \pm 0,01$ & $0,23^{\mathrm{b}} \pm 0,01$ & $0,30^{\mathrm{c}} \pm 0,01$ \\
\hline Width Radi. Dex. Dis & $0,34^{\mathrm{a}} \pm 0,05$ & $0,66^{\mathrm{b}} \pm 0,04$ & $0,80^{\mathrm{c}} \pm 0,02$ \\
\hline Width Radi. Sin. Prox & $0,26^{\mathrm{a}} \pm 0,02$ & $0,52^{\mathrm{b}} \pm 0,02$ & $0,64^{\mathrm{c}} \pm 0,02$ \\
\hline Width Radi. Sin. Cor & $0,12^{\mathrm{a}} \pm 0,01$ & $0,24^{\mathrm{b}} \pm 0,02$ & $0,30^{\mathrm{c}} \pm 0,02$ \\
\hline Width Radi. Sin. Dis & $0,32^{\mathrm{a}} \pm 0,05$ & $0,64^{\mathrm{b}} \pm 0,05$ & $0,79^{\mathrm{c}} \pm 0,05$ \\
\hline Width Ulna. Dex. Prox & $0,39^{\mathrm{a}} \pm 0,04$ & $0,87^{b} \pm 0,04$ & $1,09^{\mathrm{c}} \pm 0,04$ \\
\hline Width Ulna. Dex. Cor & $0,22^{\mathrm{a}} \pm 0,01$ & $0,43^{b} \pm 0,02$ & $0,55^{\mathrm{c}} \pm 0,03$ \\
\hline Width Ulna. Dex. Dis & $0,42^{\mathrm{a}} \pm 0,04$ & $0,86^{\mathrm{b}} \pm 0,05$ & $1,04^{\mathrm{c}} \pm 0,03$ \\
\hline Width Ulna. Sin. Prox & $0,40^{\mathrm{a}} \pm 0,03$ & $0,90^{\mathrm{b}} \pm 0,06$ & $1,12^{\mathrm{c}} \pm 0,04$ \\
\hline Width Ulna. Sin. Cor & $0,22^{\mathrm{a}} \pm 0,01$ & $0,43^{\mathrm{b}} \pm 0,02$ & $0,56^{\mathrm{c}} \pm 0,02$ \\
\hline Width Ulna. Sin. Dis & $0,44^{\mathrm{a}} \pm 0,06$ & $0,86^{\mathrm{b}} \pm 0,06$ & $1,04^{\mathrm{c}} \pm 0,03$ \\
\hline Circul Humer. Dex. Prox & $1,21^{\mathrm{a}} \pm 0,07$ & $2,52^{\mathrm{b}} \pm 0,12$ & $3,00^{\mathrm{c}} \pm 0,13$ \\
\hline Circul Humer. Dex. Cor & $0,98^{\mathrm{a}} \pm 0,21$ & $1,77^{\mathrm{b}} \pm 0,07$ & $2,20^{\mathrm{c}} \pm 0,09$ \\
\hline Circul Humer. Dex. Dis & $1,25^{\mathrm{a}} \pm 0,06$ & $2,64^{\mathrm{b}} \pm 0,12$ & $3,16^{\mathrm{c}} \pm 0,10$ \\
\hline Circul Humer. Sin. Prox & $1,23^{\mathrm{a}} \pm 0,11$ & $2,56^{\mathrm{b}} \pm 0,09$ & $3,04^{\mathrm{c}} \pm 0,16$ \\
\hline Circul Humer. Sin. Cor & $0,93^{\mathrm{a}} \pm 0,06$ & $1,82^{\mathrm{b}} \pm 0,08$ & $2,23^{\mathrm{c}} \pm 0,11$ \\
\hline Circul Humer. Sin. Dis & $1,21^{\mathrm{a}} \pm 0,08$ & $2,64^{\mathrm{b}} \pm 0,15$ & $3,21^{\mathrm{c}} \pm 0,13$ \\
\hline Circul Radi. Dex. Prox & $0,74^{\mathrm{a}} \pm 0,10$ & $1,58^{\mathrm{b}} \pm 0,12$ & $1,82^{\mathrm{c}} \pm 0,10$ \\
\hline Circul Radi. Dex. Cor & $0,51^{\mathrm{a}} \pm 0,05$ & $0,94^{\mathrm{b}} \pm 0,04$ & $1,16^{\mathrm{c}} \pm 0,10$ \\
\hline Circul Radi. Dex. Dis & $0,75^{\mathrm{a}} \pm 0,07$ & $1,39^{\mathrm{b}} \pm 0,05$ & $1,69^{\mathrm{c}} \pm 0,11$ \\
\hline Circul Radi. Sin. Prox & $0,72^{\mathrm{a}} \pm 0,05$ & $1,53^{\mathrm{b}} \pm 0,07$ & $1,83^{\mathrm{c}} \pm 0,11$ \\
\hline Circul Radi. Sin. Cor & $0,54^{\mathrm{a}} \pm 0,06$ & $0,93^{\mathrm{b}} \pm 0,06$ & $1,14^{\mathrm{c}} \pm 0,07$ \\
\hline Circul Radi. Sin. Dis & $0,74^{\mathrm{a}} \pm 0,08$ & $1,38^{\mathrm{b}} \pm 0,08$ & $1,70^{\mathrm{c}} \pm 0,13$ \\
\hline Circul Ulna. Dex. Prox & $1,06^{a} \pm 0,08$ & $2,21^{\mathrm{b}} \pm 0,11$ & $2,65^{\mathrm{c}} \pm 0,07$ \\
\hline Circul Ulna. Dex. Cor & $0,75^{\mathrm{a}} \pm 0,04$ & $1,43^{b} \pm 0,07$ & $1,78^{\mathrm{c}} \pm 0,15$ \\
\hline Circul Ulna. Dex. Dis & $1,04^{\mathrm{a}} \pm 0,08$ & $1,89 b \pm 0,11$ & $2,24^{\mathrm{c}} \pm 0,04$ \\
\hline Circul Ulna. Sin. Prox & $1,04^{\mathrm{a}} \pm 0,10$ & $2,23^{b} \pm 0,12$ & $2,62^{\mathrm{c}} \pm 0,09$ \\
\hline Circul Ulna. Sin. Cor & $0,77^{\mathrm{a}} \pm 0,06$ & $1,43^{\mathrm{b}} \pm 0,09$ & $1,74^{\mathrm{c}} \pm 0,08$ \\
\hline Circul Ulna. Sin. Dis & $1,01^{\mathrm{a}} \pm 0,11$ & $1,92^{\mathrm{b}} \pm 0,06$ & $2,29^{\mathrm{c}} \pm 0,10$ \\
\hline Weight Humer. Dex & $0,14^{\mathrm{a}} \pm 0,02$ & $1,27^{\mathrm{b}} \pm 0,11$ & $2,60^{\mathrm{c}} \pm 0,24$ \\
\hline Weight Humer. Sin & $0,14^{\mathrm{a}} \pm 0,02$ & $1,28^{\mathrm{b}} \pm 0,11$ & $2,22^{\mathrm{c}} \pm 0,24$ \\
\hline Weight Radi. Dex & $0,03^{\mathrm{a}} \pm 0,01$ & $0,26^{\mathrm{b}} \pm 0,03$ & $0,54^{\mathrm{c}} \pm 0,05$ \\
\hline Weight Radi. Sin & $0,03^{\mathrm{a}} \pm 0,01$ & $0,25^{\mathrm{b}} \pm 0,03$ & $0,54^{\mathrm{c}} \pm 0,06$ \\
\hline Weight Ulna. Dex & $0,08^{\mathrm{a}} \pm 0,02$ & $0,62^{\mathrm{b}} \pm 0,08$ & $1,27^{\mathrm{c}} \pm 0,13$ \\
\hline Weight Ulna.Sin & $0,08^{\mathrm{a}} \pm 0,01$ & $0,61^{b} \pm 0,06$ & $1,28^{\mathrm{c}} \pm 0,10$ \\
\hline Weight Meta I Dex & $0,002^{\mathrm{a}} \pm 0,0005$ & $0,01^{\mathrm{b}} \pm 0,0021$ & $0,03^{\mathrm{c}} \pm 0,0067$ \\
\hline Weight Meta I Sin & $0,002^{\mathrm{a}} \pm 0,0005$ & $0,01^{b} \pm 0,0048$ & $0,03^{\mathrm{c}} \pm 0,0063$ \\
\hline Weight Meta II Dex & $0,02^{\mathrm{a}} \pm 0,0053$ & $0,22^{\mathrm{b}} \pm 0,0147$ & $0,47^{\mathrm{c}} \pm 0,0327$ \\
\hline Weight Meta II Sin & $0,02^{\mathrm{a}} \pm 0,0042$ & $0,24^{\mathrm{b}} \pm 0,0226$ & $0,46^{\mathrm{c}} \pm 0,0356$ \\
\hline Weight Meta III Dex & $0,0075^{\mathrm{a}} \pm 0,0013$ & $0,05^{\mathrm{b}} \pm 0,0067$ & $0,12^{\mathrm{c}} \pm 0,0215$ \\
\hline
\end{tabular}




\begin{tabular}{llll} 
Weight Meta III Sin & $0,0085^{\mathrm{a}} \pm 0,0014$ & $0,05^{\mathrm{b}} \pm 0,0057$ & $0,11^{\mathrm{c}} \pm 0,0085$ \\
Weight Digit I Dex & $0,0027^{\mathrm{a}} \pm 0,0006$ & $0,02^{\mathrm{b}} \pm 0,0052$ & $0,04^{\mathrm{c}} \pm 0,0053$ \\
Weight Digit I Dex & $0,0029^{\mathrm{a}} \pm 0,0006$ & $0,01^{\mathrm{b}} \pm 0,0052$ & $0,05^{\mathrm{c}} \pm 0,0067$ \\
Weight Digit II Dex. Phal. I & $0,0079^{\mathrm{a}} \pm 0,0017$ & $0,06^{\mathrm{b}} \pm 0,0095$ & $0,1320^{\mathrm{c}} \pm 0,0063$ \\
Weight Digit II Sin. Phal. I & $0,0087^{\mathrm{a}} \pm 0,0021$ & $0,06^{\mathrm{b}} \pm 0,0082$ & $0,1270^{\mathrm{c}} \pm 0,0082$ \\
Weight Digit II Dex. Phal. II & $0,0030^{\mathrm{a}} \pm 0,0007$ & $0,02^{\mathrm{b}} \pm 0,0063$ & $0,0380^{\mathrm{c}} \pm 0,0042$ \\
Weight Digit II Sin. Phal. II & $0,0033^{\mathrm{a}} \pm 0,0007$ & $0,02^{\mathrm{b}} \pm 0,0032$ & $0,0370^{\mathrm{c}} \pm 0,0067$ \\
Weight Digit III Dex & $0,0010^{\mathrm{a}} \pm 0,0003$ & $0,0110^{\mathrm{b}} \pm 0,0040$ & $0,0170^{\mathrm{c}} \pm 0,0048$ \\
Weight Digit III Sin & $0,0010^{\mathrm{a}} \pm 0,0003$ & $0,0093^{\mathrm{b}} \pm 0,0016$ & $0,0095^{\mathrm{c}} \pm 0,0075$ \\
\hline
\end{tabular}

Superskrip berbeda pada baris yang sama menunjukkan signifikan $(\mathrm{p}<0.05)$

menunjukkan bahwa pada umur 7,21 dan 35 hari, diperoleh hasil bahwa terjadi pertumbuhan yang signifikan $(\mathrm{p}<0.05)$ terhadap nilai rata-rata panjang, lebar (proximal, corpus dan distal), keliling (proximal, corpus dan distal) dan berat pada os scapula, os coracoid dan os clavicula dan tulang-tulang alat penyusun gerak bebas yang terdiri dari os humerus, os radius, os ulna, os metacarpal I, os metacarpal II, os metacarpal III, os digiti I, ossa digiti II phalang I ossa digiti II Phalang I dan ossa digiti II Phalang II serta ossa digiti III. Pertumbuhan yang signifikan $(\mathrm{p}<0.05)$ terjadi pada umur 7 sampai 35 hari pada semua variabel, tetapi pada variabel keliling tulang dari os scapula dexter distal tidak mengalami pertumbuhan yang signifikan ( $>0.05$ ) dari umur 21 ke 35 hari.

Peningkatan pola pertumbuhan ayam broiler pada hari ke-7 sampai ke-21 lebih cepat dibandingkan saat hari ke-21 sampai ke-35, hal tersebut sesuai dengan pendapat Agustina dkk. (2013) yang menyatakan bahwa umumnya masa percepatan pertumbuhan terjadi sebelum ternak mengalami pubertas kemudian terjadi proses perlambatan. Pertumbuhan mempunyai tahap yang cepat dan lambat, dimana tahap cepat terjadi pada saat lahir sampai hewan pubertas, sedangkan tahap lambat terjadi pada saat kedewasaan tubuh telah tercapai.

Ternak mengalami pertumbuhan cepat sejak lahir hingga mencapai dewasa kelamin, semakin bertambah umur ayam, pertumbuhan tulang akan berkurang. Umur tertentu pertumbuhan tulang dan otot ayam akan berhenti karena sudah mencapai batas pertumbuhan (Ashifudin dkk., 2017). Pengamatan hari ke-21 sampai hari ke-35 ayam masih menunjukkan pertumbuhan namun mengalami perlambatan, maka asupan nutrisi pakan perlu diberikan dengan kandungan gizi yang cukup untuk memicu pembentukan daging pada ayam broiler strain Lohmann sebelum ayam telah mencapai batas pertumbuhan.

\section{KESIMPULAN}

Berdasarkan hasil penelitian pola pertumbuhan ayam broiler strain Lohmann pada osteometri tulang sayap pada umur 7, 21 dan 35 hari, diperoleh kesimpulan bahwa terdapat hasil yang signifikan $(\mathrm{p}<0.05)$ terhadap nilai rata-rata panjang, lebar (proximal, corpus dan distal), keliling (proximal, corpus dan distal) dan berat pada os scapula, os coracoid dan os clavicula dan tulang-tulang alat penyusun gerak bebas yang terdiri dari os humerus, os radius, os ulna, os metacarpal I, os metacarpal II, os metacarpal III, ossa digiti I, ossa digiti II phalang I ossa digiti II Phalang I dan ossa digiti II Phalang II serta ossa digiti III.

\section{UCAPAN TERIMA KASIH}

Peneliti mengucapkan terimakasih kepada peternakan ayam broiler strain Lohmann Kedayunan yang yang telah memberikan kesempatan bagi peneliti untuk dapat melangsungkan penelitian dan memperoleh data.

\section{DAFTAR PUSTAKA}

Agustina, D., Iriyanti, N., Mugiyono, S. 2013. Pertumbuhan dan Konsumsi Pakan pada Berbagai Jenis Itik Lokal Betina yang Pakannya di Suplementasi Probiotik. Jurnal Ilmiah Peternakan, 1(2), 691-698. 
Ashifudin, M.E., Kurnianto, Sutopo. 2017. Karakteristik morfometrik ayam kedu jengger merah dan jengger hitam generasi pertama di satker ayam marontemanggung. Jurnal Ilmu Ternak, 17(1), 40-46.

Bangun, G.D.D., Mahfudz, L.D., Sunarti, D. 2013. Pengaruh Penggunaan Tepung Rumput Laut (Gracilaria Verrucosa) Dalam Ransum Ayam Broiler Terhadap Berat Dan Ukuran Tulang Tibia Dan Tarsometatarsus. Anim. Agric. J., 2(1), 494.

Corzo, A., Moran Jr, E.T., Hoehler, D. 2002. Lysine need of heavy broiler males applying the ideal protein concept. Poult. Sci., 81, 1863-1868.

Djagra, I.B. 2002. Pertumbuhan sapi Bali; Sebuah Analisis Berdasarkan Dimensi Tubuh. Majalah Ilmiah UNUD Tahun XX1, 39, 173-182.

Harland, F.B., Oberleas, D. 2001. Effects of dietary fiber and phytat on the homeostatis and bioavailability of minerals. Di dalam: Spiller dan A Gene, editors. Handbooks of Dietary Fiberin Human Nutrition. $3^{\text {rd }}$ Ed. USA : Library of congress.

Hartadi, E.B., Dewi, W.K., Listyasari, N., Purnama, M.T.E. 2018. Studi Morfometrik pada Os Scapula Hewan Kelinci New Zealand White (Oryctolagus cuniculus). Jurnal Medik Veteriner, 1(3), 87-92.

Kartikasari, A.M., Hamid, I.S., Purnama, M.T.E., Damayanti, R., Fikri, F., Praja, R.N. 2019. Isolasi dan identifikasi bakteri Escherichia coli kontaminan pada daging ayam broiler di rumah potong ayam Kabupaten Lamongan. Jurnal Medik Veteriner, 2(1), 66-71.

Kurniawan, L.A.U., Atmomarsono, L., Djauhari, M. 2012. Pengaruh Berbagai Frekuensi Pemberian Pakan dan Pembataasan Pakan Terhadap Pertumbuhan Tulang Ayam
Broiler. Fakultas Peternakan Universitas Diponegoro. Semarang. Agromedia, 3(2), 16.

Muharlien, Achmanu, Rachmawati, R. 2011. Meingkatkan Produksi Ayam Pedaging Melalui Pengaturan Proporsi Sekam, Pasir dan Kapur sebagai Litter. Universitas Brawijaya. Malang. J. Ternak Tropika, 12(1), 38.

Murwani, R. 2010. Broiler Modern. Widya Karya. Semarang. Hal: 2-16.

Pramudyati, Y.S. 2009. Petunjuk Teknis Beternak Ayam Buras. Balai Pengkajian Teknologi Pertanian (BPTP) Sumatera Selatan. Sumatera Selatan. Hal: 5-12.

Rahayu, I., Darwati, Mu'iz, A. 2019. Morfometrik Ayam Broiler dengan Pemeliharaan Intensif dan Free Range di Daerah Tropis. Jurnal Ilmu Produksi dan Teknologi Hasil Peternakan, 7(2), 75-79.

Rahmaningtyas, I.H., Yulianto, R., Prastika, D.W., Arifin, K., Oktaviana, V., Setiabudi, R.S., Purnama, M.T.E. 2017. Efektivitas tepung teritip (cirripedia $s p$ ) terhadap pertambahan berat badan dan feed convertion ratio (fcr) ayam pedaging. Surabaya. Jurnal Agro Veteriner Universitas Airlangga, 5(2).

Rizkuna, A.U., Atmomarsono, Sunarti, D. 2014. Evaluasi Pertumbuhan Tulang ayam Kampung Umur 0-6 Minggu dengan Taraf Protein dan Suplementasi Lisin dalam Ransum. Universitas Diponegoro. JTTP, 3(3), 123.

Singh, N.S., Iadalangki, B., Anand S.D., Ramita S. 2015. Structural Variations and Their Adaptive Significances in the Bones of Some Migratory and Resident Birds. Department of Zoology, North- Eastern Hill University, Shillong. Meghalaya India, 70, 33-40. 
Triawan, A., Sudrajat, D., Anggraeni. 2013. Performa Ayam Broiler yang diberi Ransum Mengandung Neraca Kation Anion Ransum yang Berbeda. Jurnal Pertanian, 4(2), 78.

Vistro, W.A, Illahi, B.K., Muhammad, G., Nasir R., Shujat A.K., Khalid, H., Syed, K.F. 2015. Comparative Anatomical Studies on Humerus of Commercial Broiler and Desi Chicken. 6(6).
Warwick, E.J., Astuti, J.M., Hardjosubroto, W. 1990. Pemuliaan ternak. Gadjah Mada University Press. Yogyakarta.

Wilson, H.R., Boone, M.A., Arofa, A.S., Janky, D.M. 1983. Abdominal fat pad reduction in broiler with thyroactive iodinated casein. Poult. Sci., 62, 811-818.

Yuwanta, T. 2004. Dasar ternak Unggas. Penerbit Kanisius, Yogyakarta, Hal: 64-69. 